\title{
Quantification of phenylalanine hydroxylase activity by isotope-dilution liquid chromatography-electrospray ionization tandem mass spectrometry
}

\author{
Heintz, Caroline ; Troxler, Heinz ; Martinez, Aurora ; Thöny, Beat ; Blau, Nenad
}

\begin{abstract}
BACKGROUND: Residual phenylalanine hydroxylase (PAH) activity is the key determinant for the phenotype severity in phenylketonuria (PKU) patients and correlates with the patient's genotype. Activity of in vitro expressed mutant PAH may predict the patient's phenotype and response to tetrahydrobiopterin $(\mathrm{BH}(4))$, the cofactor of PAH. METHODS: A robust LC-ESI-MSMS PAH assay for the quantification of phenylalanine and tyrosine was developed. We measured PAH activity a) of the PAH mutations p.Y417C, p.I65T, p.R261Q, p.E280A, p.R158Q, p.R408W, and p.E390G expressed in eukaryotic COS-1 cells; b) in different cell lines (e.g. Huh-7, Hep3B); and c) in liver, brain, and kidney tissue from wild-type and PKU mice. RESULTS: The PAH assay was linear for phenylalanine and tyrosine (r(2) 0.99), with a detection limit of $105 \mathrm{nmol} / \mathrm{L}$ for Phe and $398 \mathrm{nmol} / \mathrm{L}$ for Tyr. Intra-assay and inter-assay coefficients of variation were $<5.3 \%$ and $<6.2 \%$, respectively, for the p.R158Q variant in lower tyrosine range. Recovery of tyrosine was $100 \%$. Compared to the wild-type enzyme, the highest PAH activity at standard conditions $(1 \mathrm{mmol} / \mathrm{L} \mathrm{L-Phe;} 200 \mathrm{~mol} / \mathrm{L} \mathrm{BH}(4))$ was found for the mutant p.Y417C (76\%), followed by p.E390G (54\%), p.R261Q (43\%), p.I65T (33\%), p.E280A (15\%), p.R158Q (5\%), and p.R408W (2\%). A relative high PAH activity was found in kidney (33\% of the liver activity), but none in brain. CONCLUSIONS: This novel method is highly sensitive, specific, reproducible, and efficient, allowing the quantification of PAH activity in different cells or tissue extracts using minimum amounts of samples under standardized conditions
\end{abstract}

DOI: https://doi.org/10.1016/j.ymgme.2011.12.025

Posted at the Zurich Open Repository and Archive, University of Zurich

ZORA URL: https://doi.org/10.5167/uzh-62427

Journal Article

Accepted Version

Originally published at:

Heintz, Caroline; Troxler, Heinz; Martinez, Aurora; Thöny, Beat; Blau, Nenad (2012). Quantification of phenylalanine hydroxylase activity by isotope-dilution liquid chromatography-electrospray ionization tandem mass spectrometry. Molecular Genetics and Metabolism, 105(4):559-665.

DOI: https://doi.org/10.1016/j.ymgme.2011.12.025 


\section{Quantification of Phenylalanine Hydroxylase Activity by Isotope-}

\section{Dilution Liquid Chromatography-Electrospray Ionization Tandem}

\section{Mass Spectrometry}

Caroline Heintz ${ }^{1}$, Heinz Troxler ${ }^{1}$, Aurora Martinez ${ }^{2}$, Beat Thöny ${ }^{1,3,4}$, Nenad Blau ${ }^{1,3,4,5 \S^{*}}$

'Division of Clinical Chemistry and Biochemistry, University Children's Hospital, Zürich, Switzerland; ${ }^{2}$ Department of Biomedicine, University of Bergen, Bergen, Norway; ${ }^{3}$ Zürich Center for Integrative Human Physiology (ZIHP), Zürich, Switzerland; ${ }^{4}$ Research Center for Children (RCC), Zürich, Switzerland; ${ }^{5}$ Division of Metabolism, University Children's Hospital, Heidelberg, Germany

${ }^{\S}$ Present address: Division of Metabolism, University Children's Hospital, Heidelberg, Germany

${ }^{*}$ Corresponding Author:

Prof. Dr. Nenad Blau

Division of Metabolism

University Children's Hospital

Steinwiesstrasse 75

$\mathrm{CH}-8032$ Zürich

Switzerland

Tel.: +4144266 7539

Fax: +41 442667169

Email: nenad.blau@kispi.uzh.ch 


\section{Keywords:}

Phenylketonuria, Tetrahydrobiopterin, Hyperphenylalaninemia, $\mathrm{PKU}, \mathrm{BH}_{4}, \mathrm{PAH}$, Liquid chromatography electrospray ionization tandem mass-spectrometry

\section{Abbreviations:}

LC-ESI-MSMS: Liquid chromatography electrospray ionization tandem mass-spectrometry Phe: Phenylalanine

Tyr: Tyrosine

$\mathrm{PAH}$ : Phenylalanine hydroxylase

PKU: Phenylketonuria

$\mathrm{BH}_{4}$ : Tetrahydrobiopterin

\section{Human genes:}

PAH: Phenylalanine hydroxylase gene (GenBank U49897.1, RefSeq NM_000277) 


\section{Abstract}

Background: Residual phenylalanine hydroxylase (PAH) activity is the key determinant for the phenotype severity in phenylketonuria (PKU) patients and correlates with the patient's genotype. Activity of in vitro expressed mutant PAH may predict the patient's phenotype and response to tetrahydrobiopterin $\left(\mathrm{BH}_{4}\right)$, the cofactor of $\mathrm{PAH}$.

Methods: A robust LC-ESI-MSMS PAH assay for the quantification of phenylalanine and tyrosine was developed. We measured PAH activity a) of the PAH mutations p.Y417C, p.I65T, p.R261Q, p.E280A, p.R158Q, p.R408W, and p.E390G expressed in eukaryotic COS1 cells; b) in different cell lines (e.g. Huh-7, Hep3B); and c) in liver, brain, and kidney tissue from wild-type and PKU mice.

Results: The PAH assay was linear for phenylalanine and tyrosine $\left(r^{2} \geq 0.99\right)$, with a detection limit of $105 \mathrm{nmol} / \mathrm{L}$ for Phe and $398 \mathrm{nmol} / \mathrm{L}$ for Tyr. Intra-assay and inter-assay coefficient of variation was $<5.3 \%$ and $<6.2 \%$, respectively, for the $p . R 158 Q$ variant in lower tyrosine range, respectively. Recovery of tyrosine was $100 \%$. Compared to the wild-type enzyme, the highest PAH activity at standard conditions (1 mmol/L L-Phe; $200 \mu \mathrm{mol} / \mathrm{L} \mathrm{BH4}$ ) was found for the mutant p.Y417C (76\%), followed by p.E390G (54\%), p.R261Q (43\%), p.I65T (33\%), p.E280A (15\%), p.R158Q (5\%), and p.R408W (2\%). A relative high PAH activity was found in kidney (33\% of the liver activity), but none in brain.

Conclusions: This novel method is highly sensitive, specific, reproducible, and efficient, allowing the quantification of PAH activity in different cells or tissue extracts using minimum amounts of samples under standardized conditions. 


\section{Introduction}

Deficiency of phenylalanine hydroxylase (PAH, EC 1.14.16.1) is causing phenylketonuria (PKU, OMIM 261600), an autosomal recessively inherited disease presenting with elevated blood phenylalanine (Phe) levels [1, 2]. The phenotypic severity of PKU is characterized by the type of mutation, and thus by residual PAH enzyme activity. The fully functional homotetrameric PAH catalyzes hydroxylation of Phe to tyrosine (Tyr) in the presence of cofactor (6R)-L-erythro-5,6,7,8-tetrahydrobiopterin $\left(\mathrm{BH}_{4}\right)$ and molecular oxygen $[3,4]$. According to the Locus Knowledgebase (PAHdb, www.pahdb.mcgill.ca), about $60 \%$ of mutations in the $P A H$ gene are missense mutations, which may lead to a misfolding of the protein $[5,6]$, disturbing the complex enzyme regulation and changes in kinetics, due to altered affinities for the Phe substrate and the $\mathrm{BH}_{4}$ cofactor.

The incidence of PKU is about 1 in 10 '000 newborns in Caucasian populations [2]. For most patients, therapy consists in a life-long dietary restriction of Phe to prevent neurological impairment. Recently, it has been reported that a subgroup of PKU patients (mild to moderate phenotype) can benefit from a pharmacological therapy with $\mathrm{BH}_{4}$ (sapropterin dihydrochloride; Kuvan ${ }^{\circledR}$ ) $[7,8]$. Newborn screening program for PKU, initially based on the Guthrie test [9], has been established for the early detection of PKU patients. Today, electrospray tandem mass-spectrometry (ESI-MSMS or TMS) is the method of choice for fast screening and monitoring of Phe and Tyr levels in dried blood spots (DBS) [10].

Of the over 550 disease-causing mutations listed in the PAHdb [11], 88 were expressed in different in vitro cell systems to estimate the residual PAH activity. Expression systems like Escherichia coli, eukaryotic cell lines, or cell-free systems were most commonly used systems [12-14]. In addition to cell systems, PAH activity was studied in rat liver biopsy samples [15]. Expression of recombinant PAH in bacteria was applied for characterization of physical and chemical properties of the enzyme [16].

Previous methods for $\mathrm{PAH}$ activity measurement were based on the determination of ${ }^{14} \mathrm{C}$-labelled Tyr produced [3] or release of ${ }^{3} \mathrm{H}$ [17]. Other methods are based on detection of Tyr by fluorescence [18], colorimetric assays [19], or fluorescence monitoring [20]. Recently 
described method by Gersting et al. [20] was developed for characterization of purified mutant $\mathrm{PAH}$ proteins at different Phe and $\mathrm{BH}_{4}$ concentrations.

In our novel assay, we applied liquid chromatography (LC) ESI-MSMS for the quantification of Tyr produced from Phe. Prior to analysis, the amino acids are derivatized to propyl chloroformate derivatives, using the commercially available Phenomenex EZ:faast ${ }^{\mathrm{TM}}$ kit. Our method allows for short analysis times and higher limit of detection and is optimized for determination of $\mathrm{PAH}$ enzyme activity of recombinantly expressed mutant proteins in COS-1 and other cell lines, as well as in mice liver, kidney, and brain. Thus, it allows comparison between different mutant proteins at standard conditions.

\section{Materials and Methods}

\section{Materials}

The Phenomenex EZ:faast ${ }^{T M}$ kit for LC ESI-MSMS amino acid analysis was purchased from Phenomenex (Torrance, CA, USA). L-phenylalanine- $d_{5}$ and L-tyrosine- $d_{4}$ standard reagents were purchased from Cambridge Isotope Laboratories, Inc. (Andover, MA, USA) whereas $L$-phenylalanine- $d_{8}$ was obtained from $C / D / N$ Isotopes Inc. (Pointe Claire, Quebec, Canada). L-Phenylalanine and L-tyrosine, as well as the DMEM cell culture medium were purchased from Sigma Aldrich (St. Louis, MO, USA). RPMI 1640 medium was from Invitrogen (San Diego, CA, USA). $\mathrm{BH}_{4}$ dihydrochloride was obtained from Schircks Laboratories (Jona, Switzerland). Mouse tissues were extracted from C57BL/6 (wild-type) or C57BI/6-Pah ${ }^{\text {enu2 }}$ (PKU) [21] mice strains.

\section{Expression plasmid preparation}

The expression plasmid pCMV-FLAG-PAH (Promoter-N-Fusion-PAH) was received as courtesy gift from L.R. Desviat [22]. Mutations in the human $P A H-c D N A$ sequence were introduced by site-directed mutagenesis, using QuikChange XL kit from Agilent Technologies (Santa Clara, CA, USA) and confirmed by sequencing analysis using BigDye Terminator Cycle sequencing v1.1 (Applied Biosystems) on an ABI Prism 3100 Sequencer. 
Transfection of cells and preparation of mouse tissue

Cell lines (COS-1, Hep3B, HuH-7) were cultured either in DMEM or RPMI1640 (HaCat, lymphoblasts) medium, with appropriate additives, at $37^{\circ} \mathrm{C}$ under $5 \% \mathrm{CO}_{2}$. One day prior to transfection, COS-1 cells were seeded at $2 \times 10^{5} \mathrm{cell} / \mathrm{ml}$ in $10-\mathrm{cm}$ dishes. Transfection experiments were performed using Fugene 6 (Roche Diagnostics, Mannheim, Germany) according to manufacturer's recommendations. Hereby, $13 \mu \mathrm{g}$ of the pCMVFLAG-PAH plasmid (either wild-type or mutant) were co-transfected with $2 \mu \mathrm{g}$ of pSV- $\beta$ gal reporter plasmid (Promega, Madison, USA). Transfected cells were harvested after 48 hours for determination of $\mathrm{PAH}$ activity or flash-frozen in liquid $\mathrm{N}_{2}$ for storage at $-80^{\circ} \mathrm{C}$.

Transfection efficiency was verified by determining $\beta$-galactosidase activity in $5 \mu \mathrm{l}$ lysate in PAH assay cell lysis buffer (1xPBS pH 7.4, $0.25 \mathrm{M}$ sucrose, Complete protease inhibitors cocktail (Roche)) using in-situ $\beta$-galactosidase enzyme assay system (Promega, Madison, USA). PAH activities of wild-type and mutants were normalized according to transfection efficiency.

Frozen mouse tissues were lysed in homogenization buffer (10 $\mu / \mathrm{mg}$ tissue), as described in [23], and homogenized using Qiagen TissueLyser II at $4{ }^{\circ} \mathrm{C}$. After centrifugation at $13^{\prime} 000 \mathrm{~g}$ and $4^{\circ} \mathrm{C}$ for $30 \mathrm{~min}$, supernatants were kept frozen at $-80^{\circ} \mathrm{C}$.

\section{PAH activity assay}

Cell lysates were prepared and enzyme activity was determined using previously described methods [24]. Briefly, assay conditions included pre-incubation at $25^{\circ} \mathrm{C}$ with L-Phe $(1 \mathrm{mmol} / \mathrm{L})$ for 4 minutes, then $\mathrm{Fe}\left(\mathrm{NH}_{4}\right)_{2}\left(\mathrm{SO}_{4}\right)_{2}(100 \mu \mathrm{mol} / \mathrm{L})$ was added, and incubation was continued for one more minute. After 5 minutes total pre-incubation time, $\mathrm{BH}_{4}(200 \mu \mathrm{mol} / \mathrm{L}$ for cell extracts or $75 \mu \mathrm{mol} / \mathrm{L}$ for mouse tissue) was added to start the reaction. Between 2.5 and $20 \mu \mathrm{l}(2-165 \mu \mathrm{g})$ of total protein lysate extracted from cells or mouse tissue were used for activity measurements. The applied total protein amount depended on lysate type, transfected, non-transfected, or mouse tissue samples. It was generally higher for sample 
types with low activity where only little amounts of Tyr were produced. Initially, this was determined empirically by measuring a series of increasing total protein amounts for each sample type to determine the measurable linear range. Reaction time was 2 minutes for mouse tissue lysates and 15 minutes for cell lysates. Short incubation time reduces any possible chaperone-like effect of $\mathrm{BH}_{4}$. The amount of Tyr produced was determined by LC ESI-MSMS (see below).

Protein concentrations of all sample types were determined using Pyrogallol Red protein dye binding assay [25] after completion of PAH assay due to low stability of protein lysates. Specific $\mathrm{PAH}$ activities are expressed in $\mathrm{mU}$ per $\mathrm{mg}$ total protein to account for differences in total protein amount and with $\mathrm{mU}$ equal to nmol L-Tyr produced per minute.

\section{Stock solution preparation and calibration}

Labeled internal standard stock solutions $\left(10 \mathrm{mmol} / \mathrm{L}\right.$ Phe- $\mathrm{d}_{5}$ or $10 \mathrm{mmol} / \mathrm{L} \mathrm{Tyr}-\mathrm{d}_{4}$ ) were prepared in $50 \mathrm{mmol} / \mathrm{L} \mathrm{HCl}$, stored at $-20^{\circ} \mathrm{C}$, and freshly diluted to working concentrations (see sample preparation). Stock solutions of non-labeled Phe $(50 \mathrm{mmol} / \mathrm{L})$ and $\operatorname{Tyr}(8 \mathrm{mmol} / \mathrm{L})$ were prepared for calibration curves in $50 \mathrm{mmol} / \mathrm{L} \mathrm{HCl}$ and stored at $20^{\circ} \mathrm{C}$.

Working solutions for calibration curves were freshly prepared from the non-labeled stock solutions in $\mathrm{H}_{2} \mathrm{O}$ from 100 to $700 \mu \mathrm{mol} / \mathrm{L}$ Phe and 4 to $350 \mu \mathrm{mol} / \mathrm{L}$ Tyr (Table 1$)$. In order to include the matrix effect to the calibration curves, $20 \mu \mathrm{l}$ of COS-1 non-transfected cell lysate was added to the calibration samples.

\section{Sample preparation and derivatization}

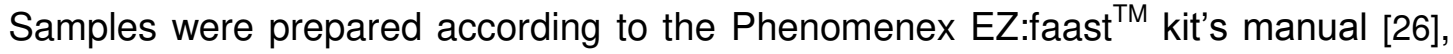
with the following modifications: prior to amino acid extraction and derivatization, $20 \mu \mathrm{L}$ of each internal standard solution containing $100 \mu \mathrm{mol} / \mathrm{LPhe}-\mathrm{d}_{5}$ and $20 \mu \mathrm{mol} / \mathrm{L}$ Tyr- $\mathrm{d}_{4}$ (in 50 $\mathrm{mmol} / \mathrm{L} \mathrm{HCl}$ ) were added to $20 \mu \mathrm{L}$ of sample lysate. Using the kit's reagents, the amino acids are derivatized with propyl chloroformate resulting in the addition of a propyl formate group, 
and a propyl group at the amine group, and the carboxylic group of the amino acids, respectively. The hydroxy group of Tyr is also derivatized by the addition of a propyl formate group.

\section{Instrumentation}

For RP (reversed phase)-HPLC separation of amino acids, a $250 \times 2 \mathrm{~mm} \mathrm{C18} \mathrm{column}$ (Phenomenex EZ:faast ${ }^{\mathrm{TM}}$ ) was used. The derivatized amino acids were separated using the following program: (i) isocratic flow $75 \%$ solvent B for 6 min; (ii) linear gradient from $75 \%$ to 95\% solvent B (v/v) in 9 min; (iii) linear gradient from 95\% to $100 \%$ solvent B in $0.1 \mathrm{~min}$; (iv) isocratic flow $100 \%$ solvent B for 3 min; (v) linear gradient from $100 \%$ to $75 \%$ solvent B in $0.1 \mathrm{~min}$; (vi) isocratic flow $75 \%$ solvent $B$ for $2 \mathrm{~min}$. Solvents $A$ and B were $10 \mathrm{mmol} / \mathrm{L}$ ammonium formate in $\mathrm{H}_{2} \mathrm{O}$ and $10 \mathrm{nmol} / \mathrm{L}$ ammonium formate in methanol, respectively. Flow rate was $150 \mu \mathrm{L} / \mathrm{min}$, and the injection volume was $10 \mu \mathrm{L}$.

A PerkinElmer SCIEX API 2000 LC-ESI-MSMS system equipped with a PerkinElmer Series 200 autosampler and two PerkinElmer Series 200 micro pumps were used for LC-ESI MSMS analysis. Amino acids were acquired using the multiple reaction mode (MRM) positive ion mode, with the following transitions: $294 \rightarrow 206$ (Phe), $299 \rightarrow 211$ (Phe- $d_{5}$ ), 302 $\rightarrow 214$ $\left(\right.$ Phe- $\left.-d_{8}\right), 396 \rightarrow 308(T y r)$, and $400 \rightarrow 312\left(T y r-d_{4}\right), 403 \rightarrow 315\left(T y r-d_{7}\right)$. The dwell time was $500 \mathrm{~ms}$. Mass spectra were acquired in the time range of 6 to 20 minutes.

\section{Immunoquantification by Western Blot}

Five to $50 \mu \mathrm{g}$ of lysate from activity assay was used for verifying $\mathrm{PAH}$ expression in the various cell lines or mouse tissue samples by Western blotting, using commercially available anti-PAH antibody PH8 (Abcam, Cambridge, UK) and donkey anti-goat IgG-HRP (Santa Cruz Biotechnology, CA, USA). Antibody binding was detected by enhanced chemiluminescence (Amersham $\mathrm{ECL}^{\mathrm{TM}}$ ) as described by the manufacturer's instructions (GE Healthcare, CT, USA). 


\section{Limit of detection}

The limit of detection (LOD) was determined by measuring six blank samples of nontransfected COS-1 cell lysate with very low amounts of Phe and Tyr using the following formula:

LOD $=(($ mean +3.3$) *$ standard deviation $) /$ slope

The limit of quantification (LOQ) for Phe and Tyr was calculated as follows:

$$
\mathrm{LOQ}=((\text { mean }+10) * \text { standard deviation }) / \text { slope }
$$

\section{Results}

\section{Linearity and limit of detection}

Figure 1 depicts linear regression of calibration standards for Phe and Tyr. Both calibration curves are linear with correlation coefficients of $r^{2} \geq 0.99$.

The LOD was $105 \mathrm{nmol} / \mathrm{L}$ for Phe and $398 \mathrm{nmol} / \mathrm{L}$ for Tyr and LOQ $147 \mathrm{nmol} / \mathrm{L}$ for Phe and $574 \mathrm{nmol} / \mathrm{L}$ for Tyr.

\section{Imprecision and recovery}

Inter- and intra-assay analyses were performed with the wild-type enzyme, with medium activity (p.R261Q), and low activity (p.R158Q) PAH variants, transfected into COS-1 cells. Six samples were each prepared either on the same day (intra-assay) or during the period of two weeks (inter-assay). Table 2 summarizes the intra- and inter-assay imprecision measurements of the method.

The intra-assay coefficient of variation (CV) varied between $2.4 \%$ and $10.8 \%$ and between $2.7 \%$ and $8.9 \%$ for Tyr and Phe, respectively (Table 2). The inter-assay imprecision data for Tyr and Phe ranges from 5.3\% to $14.3 \%$ (Table 2). Comparable CVs in the intra- and inter-assays show that the PAH assay samples are stable over more than 2 weeks at $-20^{\circ} \mathrm{C}$.

The recovery of $100 \mu \mathrm{mol} / \mathrm{L}$ exogenous Tyr added to the variant PAH p.R261Q after PAH assay was $100 \%$ (data not shown). 


\section{Analytical performance}

Three characteristic parameters, retention time, mother ion mass, and daughter ion mass were measured in the LC-ESI-MSMS method for each analyte, e.g. $12.59 \mathrm{~min}, \mathrm{~m} / \mathrm{z} 396$ Da and m/z 308 for Tyr. Figure 2a shows a representative chromatogram of a wild-type PAH assay sample with the peak-pairs at 11.0 minutes representing Phe $(294 \rightarrow 206)$ and IS-Phe $(299 \rightarrow 211)$ and at 12.6 minutes assigned to Tyr $(396 \rightarrow 308)$ and IS-Tyr $(400 \rightarrow 312)$. The peaks at 9.0 and 12.2 minutes correspond to $d_{3}$-methionine and homophenylalanine and are the internal standards included in the Phenomenex EZ:faast ${ }^{\mathrm{TM}} \mathrm{kit}$

\section{PAH activity assay}

The linearity of the PAH enzyme assay was investigated using transfected COS-1 cells with human wild-type $\mathrm{PAH}$. The reaction time was optimized to 15 minutes. As demonstrated in Figure 2b, Tyr production increased linearly with the amount of protein. However, the linear range of assay is rather small $(<250 \mu \mathrm{mol} / \mathrm{L})$ and $\mathrm{PAH}$ activity decreases with increasing Tyr production, due to reagent availability in the reaction mixture and possible product inhibition. All mutants produced lower amounts of Tyr at similar reaction times, compared with the wild-type enzyme. Stability of PAH during the reaction is critical and short reaction time should be used at low protein concentrations $(<30 \mu \mathrm{g}$ for the wild-type PAH and $<165 \mu \mathrm{g}$ for low-activity mutants).

The wild-type PAH activity in COS-1 cells was $43.9 \pm 14.5 \mathrm{mU} / \mathrm{mg}$ protein under standard reaction conditions (15 minutes reaction time and $5 \mu$ l cell lysate). PAH intra-assay variation determined in triplicate was $7.3 \%, 6.4 \%$, and $7.5 \%$ for the wild-type, p.R261Q and p.I65T in COS-1 cells, respectively.

Comparative analyses of activity for wild-type PAH activity in transfected COS- 1 cells using a HPLC-based assay with fluorimetric detection [27] provided similar values of activity for wild-type (38 $\pm 2 \mathrm{mU} / \mathrm{mg}$ ) and R261Q mutant (16 $\pm 1 \mathrm{mU} / \mathrm{mg})$. However, this HPLC based 
analysis requires $>30 \mu \mathrm{g}$ of protein in each assay, i.e. 1.5-6 fold higher than in the LC-ESILC-ESI-MSMS assay at the selected conditions.

\section{PAH mutations found in PKU patients}

In order to further evaluate the LC-ESI-MSMS method, we determined PAH activity of several known PAH mutations, in addition to p.R261Q and p.R158Q used in the method characterization and development (see above). Figure 3a shows the percent of PAH mutant activities compared to the wild-type activity for the I65T (33\%), R261Q (43\%), R158Q (5\%), R408W (2\%) and E390G (54\%) proteins.

These mutations have previously been tested in different in vitro systems, but we also analyzed two novel PAH mutations p.E280A and p.Y417C, recently reported in Turkish PKU patients [28] (Figure 3a). While a severe p.E280A mutation exhibits only $15 \%$ of the wild-type PAH activity, a mild p.Y417C mutation was almost as active as the wild-type enzyme (76\%). All mutant PAH activities were normalized for $\beta$-galactosidase, which was co-transfected into COS-1 cells.

Figure $3 \mathrm{~b}$ illustrates the different PAH mutant proteins by Western blot analysis. All of the PAH mutant proteins with rather low activity also present with reduced amounts of PAH protein, when compared to the wild-type (Figure 3c). The only exception is $p . R 158 Q$ with a very low activity and substantial amount of protein. PAH expression was normalized for $\beta$ actin expression in these COS- 1 cells and quantified by densitometry.

\section{PAH activity in mouse tissue}

The quantification of PAH activity with the novel LC-ESI-MSMS method is not only restricted to cell extracts, but can also be used for animal tissues. For this purpose, we measured PAH activity in liver, kidney, and brain tissue from wild-type (C57BL/6) or PKU mice (C57BI/6-Pah $\left.{ }^{\text {enu2}}\right)$.

Figure 4a shows PAH activity in liver, kidney and brain extracts from the wild-type and PKU mice. As expected, the highest activity was found in liver of the wild-type mouse. A relatively high $\mathrm{PAH}$ activity (33\% of the liver) was found in the kidney, whereas in tissues 
from the PKU mice no PAH activity was detectable. No PAH activity was observed in brain extracts from the wild-type animals.

The Western blot analysis shows high amounts of PAH protein in the wild-type mice extracts from liver and kidney, while in the same organs of the PKU mice bands of the PAH protein were detected despite no activity (Figure 4b). These results correlate well with the enzyme activity measurements for the wild-type mouse (Figure 4a). The PAH expression seems to appear as two signals in Western blot analysis. This double bond of PAH has previously been observed for $\mathrm{PAH}$ in tissues, when expressed in eukaryote systems, and was found to be the result of an apparent electrophoretic shift of the Ser-16 phosphorylated enzyme [4].

\section{PAH activity in different cell lines}

For in vitro PAH expression studies, liver or kidney mammalian cells (organs with highest PAH activity) exhibit the most similar physiological environment. However, these cell lines might exhibit endogenous PAH activity that interfere with activity from transfected PAH. Therefore, we investigated PAH expression and PAH activity in several common hepatic cell lines (e.g. HepG2, Hep3B and HuH-7) (Figure 5a). No PAH activity or protein was detected in HepG2 cells, and only low endogenous activity was found in Hep3B and $\mathrm{HuH}-7$ cells (Figures $5 \mathrm{a}$ and $5 b)$.

Using the labeled Phe- $\mathrm{d}_{8}$ isotope in the PAH assay, which is consequently oxidized to Tyr- $d_{7}$, we were able to distinguish the assay product Tyr- $d_{7}$ from Tyr from the cell extracts. We found that PAH activities using Phe- $\mathrm{d}_{8}$ are lower than using non-labeled Phe (32.5 $\mathrm{mU} / \mathrm{mg}$ versus $43.7 \mathrm{mU} / \mathrm{mg}$ protein) due to a possible isotope effect, but high enough to discriminate between different PAH mutants. The same reduction accounts for the $\mathrm{p} . \mathrm{R} 261 \mathrm{Q}$ mutant, but the activity of this mutant is consistently measured to be $40 \%$ of wild-type PAH activity both with Phe or Phe- $\mathrm{d}_{8}$ as substrates. 
Figure 5b shows wild-type $\mathrm{PAH}$ protein expression in Hep3B, $\mathrm{HuH}-7$, and $\mathrm{COS}-1$ cells, compared to non-transfected cells. No wild-type PAH protein could be detected from non-transfected Hep3B, HuH-7, and COS-1 cell lines with $20 \mu \mathrm{g}$ of total protein analyzed.

Furthermore, no PAH activity or protein was detected in EBV-transformed lymphocytes, even though PAH transcript can be amplified from their RNA [29]. Also, no PAH activity and transcript could be detected in the HaCat cell line (human adult low calcium high temperature keratinocytes).

\section{Discussion}

Molecular mechanisms of PKU and other hyperphenylalaninemias were established over several decades through investigations of mutations within the $P A H$ gene [30]. Based on genotype findings and description of $\mathrm{BH}_{4}$-responsive forms of $\mathrm{PKU}$ [31], functional assays of mutation effects in vitro have proven to be very fruitful for the characterization of $P A H$ mutations, building a bridge between patient and pure protein. Although, these data sets tend to overestimate $\mathrm{PAH}$ activities in vivo. Residual in vitro $\mathrm{PAH}$ activity was shown to correlate with the patient's phenotype [32]. Thus, knowing patient's residual PAH activity can be relevant for selecting therapeutic options, the likely Phe tolerance, and the expected response to $\mathrm{BH}_{4}[28]$.

In this study, we have developed a new method for the quantification of the amino acids Phe and Tyr by LC ESI-MSMS, as a basis for the measurement of PAH activity. The EZ:faast ${ }^{\mathrm{TM}}$ sample preparation (amino acid extraction, washing and derivatization steps are included in the procedure) was originally developed for the rapid processing and measuring of biological fluids in clinical analyses. We optimized this procedure to the quantitative determination of $\mathrm{PAH}$ activity in an in vitro expression system and in various mouse tissues. Using the EZ:faast ${ }^{\mathrm{TM}}$ kit, sample preparation is fast and time consuming steps, such as protein precipitation, removal of interfering substances (e.g. salts and other buffer components), or elaborating derivatization procedures, can be omitted. Furthermore, since our mass spectrometric analysis technique enables the application of isotopically labeled 
internal standards (Phe- $\mathrm{d}_{5}$ and Phe- $\mathrm{d}_{8}$, Tyr- $\mathrm{d}_{4}$ ), our method is highly specific and reliable. It is suitable for the quantification of Phe and Tyr even in very complex biological matrices. Its fast and simple sample preparation procedure allows for the analysis of a big sample series in a short amount of time.

The calibration range of Phe and Tyr is variable and can be selected according to the type of in vitro expression system and predicted enzyme activity. Low coefficients of variation in intra- and inter-assay confirm that the method can be applied in the nanomolar range.

The PAH assay method used for the quantification by MS is a discontinuous assay commonly used in PAH mutation studies. The time between extraction of total protein from cultured cells and enzymatic reaction is critical and should be kept short. Our expression system in COS-1 cells shows a high transfection efficiency and protein expression, therefore only little amounts of total protein are required for assessing activity. We verified this method, to determine activities in the linear range and diluted the proteins accordingly. Thus, other systems with lower protein expression can be easily quantified by this new method.

Every PAH mutant was assessed in at least three different transfection systems and quantification experiments. The results of each mutant, expressed as percent of wild-type $\mathrm{PAH}$, are well in accordance with previously published data for the same mutations [33]. The slight differences found were due to the fact that previously reported $\mathrm{PAH}$ activity measurements were performed under different assay conditions and using several substrates with different affinities (e.g. $\mathrm{BH}_{4}, 6$-methyl-tetrahydropterin or 6,7-dimethyltetrahydropterin) $[3,12]$. In previous reports, in vitro activities for some mutations (e.g. p.R261Q) ranged between $24-100 \%$, depending on the expressions system and assay used [34, 35].

Two new PKU mutations, p.E280A and p.Y417C, are described in our study, which were detected among a larger Turkish patients cohort and were not previously expressed in vitro. The activities determined for p.E280A and p.Y417C mutants (15\% and $76 \%$ of the wildtype $\mathrm{PAH}$ ) correlate with the severity of hyperphenylalaninemia in the corresponding patients. 
The quantification of Phe and Tyr is not only limited to cell extracts, but can also be used on various mouse tissues. The advantages of using Phenomenex EZ:faast ${ }^{\mathrm{TM}}$ kit also apply to these complex biological samples, omitting interferences from the mixtures. Thus, the liver is not the only site of PAH expression in humans and animals. Up to $40 \% \mathrm{PAH}$ activity has been reported in the kidneys, as compared to the liver in human tissue [36]. In this study, we report $33 \%$ of kidney PAH activity in wild-type mouse tissue in relation to PAH activity in liver, in accordance with previous data in rodents [37]. In addition to liver and kidneys, significant PAH activity and expressions were also reported in pancreas tissue [36, 38]. Keratinocytes were suggested as potential target for PKU gene therapy [39] and claimed to contain intact PAH metabolism [40], however with our assay no $\mathrm{PAH}$ activity or protein was detected in these cells.

In contrast to the method published by Gersting et al. [20], our method measures $\mathrm{PAH}$ activity at standardized Phe and $\mathrm{BH}_{4}$ concentrations and may be a good screening method for selection of mutations of interest for the kinetic studies at different Phe and $\mathrm{BH}_{4}$ concentrations [41]. Thus, the main application of this new method will be the quantification of the relative in vitro PAH activity in patients with PKU by expressing mutant proteins in COS-1 cells. A recent study with a large cohort of Turkish PKU patients suggested that both the phenotype and $\mathrm{BH}_{4}$-responsiveness are genotype-dependent and that the residual PAH activity is a good predictor for the severity of the disease [28]. Finally, this method can easily be extended to other amino acids since labeled compounds are available as internal standards for quantification.

\section{Acknowledgments}

This work was supported by the Swiss National Science Foundation grant no. 31003A119982 (to NB and BT). We would like to thank Dr. L Ruiz Desviat for providing us with the PAH expression plasmid and Dr. HM Viecelli for the mouse tissue samples and Dr. R. Dummer for keratinocytes. In addition we thank the mass spectrometry group of the Children's Hospital in Zurich for expert technical assistance. 


\section{References}

1. Scriver CR, Kaufman S. Hyperphenylalaninemia: Phenylalanine hydroxylase deficiency. In The Metabolic and Molecular Bases of Inherited Disease. (Scriver CR, Beaudet AL, Sly WS, Valle D, Childs B, Vogelstein B, Eds.) 8th ed. New York: McGraw-Hill; p. 1667-1724, 2001.

2. Blau N, Van Spronsen FJ, Levy HL. Phenylketonuria. Lancet 376:1417-1427.2010

3. Kaufman S. The phenylalanine hydroxylating system. Adv Enzymol Relat Areas Mol Biol 67:77-264.1993

4. Bjorgo E, Knappskog PM, Martinez A, Stevens RC, Flatmark T. Partial characterization and three-dimensional-structural localization of eight mutations in exon 7 of the human phenylalanine hydroxylase gene associated with phenylketonuria. Eur J Biochem 257(1):1-10.1998

5. Pey AL, Stricher F, Serrano L, Martinez A. Predicted effects of missense mutations on native-state stability account for phenotypic outcome in phenylketonuria, a paradigm of misfolding diseases. Am J Hum Genet 81(5):1006-1024.2007

6. Gersting SW, Kemter KF, Staudigl M, Messing DD, Danecka MK, Lagler FB, Sommerhoff CP, Roscher AA, Muntau AC. Loss of function in phenylketonuria is caused by impaired molecular motions and conformational instability. Am J Hum Genet 83(1):5-17.2008 7. Muntau AC, Röschinger W, Habich M, Demmelmair H, Hoffmann B, Sommerhoff CP, Roscher AA. Tetrahydrobiopterin as an alternative treatment for mild phenylketonuria. N Engl J Med 347:2122-2132.2002

8. Blau N. Sapropterin dihydrochloride for phenylketonuria and tetrahydrobiopterin deficiency. Expert Rev Endocrinol Metab 5(4):483-494.2010

9. Guthrie R, Susi A. A simple phenylalanine method for detecting phenylketonuria in large populations of newborn infants. Pediatrics 32:338-343.1963

10. Chace DH, Millington DS, Terada N, Kahler SG, Roe CR, Hofman LF. Rapid diagnosis of phenylketonuria by quantitative analysis for phenylalanine and tyrosine in neonatal blood spots by tandem mass spectrometry. Clin Chem 39(1):66-71.1993

11. Scriver CR, Waters PJ, Sarkissian C, Ryan S, Prevost L, Cote D, Novak J, Teebi S, Nowacki PM. PAHdb: a locus-specific knowledgebase. Hum Mutat 15(1):99-104.2000 12. Waters PJ, Parniak MA, Nowacki P, Scriver CR. In vitro expression analysis of mutations in phenylalanine hydroxylase: linking genotype to phenotype and structure to function. Hum Mutat 11(1):4-17.1998

13. Kwok SC, Ledley FD, DiLella AG, Robson KJ, Woo SL. Nucleotide sequence of a fulllength complementary DNA clone and amino acid sequence of human phenylalanine hydroxylase. Biochemistry 24(3):556-561.1985 
14. Ledley FD, Grenett HE, DiLella AG, Kwok SC, Woo SL. Gene transfer and expression of human phenylalanine hydroxylase. Science 228(4695):77-79.1985

15. Nielsen $\mathrm{KH}$. Rat liver phenylalanine hydroxylase. A method for the measurement of activity, with particular reference to the distinctive features of the enzyme and the pteridine cofactor. European journal of biochemistry / FEBS 7(3):360-369.1969

16. Martinez A, Knappskog PM, Olafsdottir S, Doskeland AP, Eiken HG, Svebak RM, Bozzini M, Apold J, Flatmark T. Expression of recombinant human phenylalanine hydroxylase as fusion protein in Escherichia coli circumvents proteolytic degradation by host cell proteases. Isolation and characterization of the wild-type enzyme. The Biochemical journal 306 ( Pt 2):589-597.1995

17. Guroff $G$, Rhoads CA, Abramowitz A. A simple radioisotope assay for phenylalanine hydroxylase cofactor. Analytical biochemistry 21(2):273-278.1967

18. Bailey SW, Ayling JE. An assay for picomole levels of tyrosine and related phenols and its application to the measurement of phenylalanine hydroxylase activity. Anal Biochem 107(1):156-164.1980

19. Udenfriend S, Cooper JR. The chemical estimation of tyrosine and tyramine. The Journal of biological chemistry 196(1):227-233.1952

20. Gersting SW, Staudigl M, Truger MS, Messing DD, Danecka MK, Sommerhoff CP, Kemter KF, Muntau AC. Activation of phenylalanine hydroxylase induces positive cooperativity towards the enzyme's natural cofactor. J Biol Chem 285:30686-30697.2010 21. Shedlovsky A, McDonald JD, Symula D, Dove WF. Mouse models of human phenylketonuria. Genetics 134(4):1205-1210.1993

22. Aguado C, Perez B, Ugarte M, Desviat LR. Analysis of the effect of tetrahydrobiopterin on PAH gene expression in hepatoma cells. FEBS Lett 580(7):16971701.2006

23. Elzaouk L, Leimbacher W, Turri M, Ledermann B, Bürki K, Blau N, Thöny B. Dwarfism and low IGF-1 due to dopamine depletion in Pts-/- mice rescued by feeding neurotransmitter precursors and H4-biopterin. J Biol Chem 278:28303-28311.2003

24. Pey AL, Ying M, Cremades N, Velazquez-Campoy A, Scherer T, Thony B, Sancho J, Martinez A. Identification of pharmacological chaperones as potential therapeutic agents to treat phenylketonuria. J Clin Invest.2008

25. Watanabe N, Kamei S, Ohkubo A, Yamanaka M, Ohsawa S, Makino K, Tokuda K. Urinary protein as measured with a pyrogallol red-molybdate complex, manually and in a Hitachi 726 automated analyzer. Clinical chemistry 32(8):1551-1554.1986

26. Phenomenex. Ez:Faast (easy-fast) amino acid sample testing kit manual. Torrance, CA: Phenomenex.2001 
27. Doskeland AP, Doskeland SO, Ogreid D, Flatmark T. The effect of ligands of phenylalanine 4-monooxygenase on the cAMP-dependent phosphorylation of the enzyme. The Journal of biological chemistry 259(18):11242-11248.1984 28. Dobrowolski SF, Heintz C, Miller T, Ellingson CR, Ellingson CC, Özer I, Gökcay G, Baykal T, Thöny B, Demirkol M, Blau N. Molecular genetics and impact of residual in vitro phenylalanine hydroxylase activity on tetrahydrobiopterin-responsiveness in Turkish PKU population. Mol Genet Metab 10:116-121.2011

29. Ramus SJ, Forrest SM, Cotton RG. Illegitimate transcription of phenylalanine hydroxylase for detection of mutations in patients with phenylketonuria. Hum Mutat 1(2):154158.1992

30. Güttler F, Guldberg P. Mutations in the phenylalanine hydroxylase gene: genetic determinants for the phenotypic variability of hyperphenylalaninemia. Acta Paediatr Suppl 407:49-56.1994

31. Kure S, Hou DC, Ohura T, Iwamoto H, Suzuki S, Sugiyama N, Sakamoto O, Fujii K, Matsubara Y, Narisawa K. Tetrahydrobiopterin-responsive phenylalanine hydroxylase deficiency. J Pediatr 135(3):375-378.1999

32. Okano Y, Eisensmith RC, Güttler F, Lichter-Konecki U, Konecki DS, Trefz FK, Dasovich M, Wang T, Henriksen K, Lou H, et al. Molecular basis of phenotypic heterogeneity in phenylketonuria. N Engl J Med 324(18):1232-1238.1991

33. Scriver CR, Hurtubise M, Konecki D, Phommarinh M, Prevost L, Erlandsen H, Stevens R, Waters PJ, Ryan S, McDonald D, Sarkissian C. PAHdb 2003: what a locusspecific knowledgebase can do. Hum Mutat 21(4):333-344.2003

34. Okano Y, Wang T, Eisensmith RC, Guttler F, Woo SL. Recurrent mutation in the human phenylalanine hydroxylase gene. American journal of human genetics 46(5):919924.1990

35. Gjetting T, Petersen M, Guldberg P, Guttler F. In vitro expression of 34 naturally occurring mutant variants of phenylalanine hydroxylase: correlation with metabolic phenotypes and susceptibility toward protein aggregation. Mol Genet Metab 72(2):132143.2001

36. Lichter-Konecki U, Hipke CM, Konecki DS. Human phenylalanine hydroxylase gene expression in kidney and other nonhepatic tissues. Mol Genet Metab 67(4):308-316.1999 37. Hsieh MC, Berry HK. Distribution of phenylalanine hydroxylase (EC 1.14.3.1) in liver and kidney of vertebrates. The Journal of experimental zoology 208(2):161-167.1979 38. Tourian A, Goddard J, Puck TT. Phenylalanine hydroxylase activity in mammalian cells. Journal of cellular physiology 73(2):159-170.1969 
39. Christensen R, Guttler F, Jensen TG. Comparison of epidermal keratinocytes and dermal fibroblasts as potential target cells for somatic gene therapy of phenylketonuria. Mol Genet Metab 76(4):313-318.2002

40. Schallreuter KU, Zschiesche M, Moore J, Panske A, Hibberts NA, Herrmann FH, Metelmann HR, Sawatzki J. In vivo evidence for compromised phenylalanine metabolism in vitiligo. Biochem Biophys Res Commun 243(2):395-399.1998

41. StaudigI M, Gersting SW, Danecka MK, Messing DD, Woidy M, Pinkas D, Kemter KF, Blau N, Muntau AC. The interplay between genotype, metabolic state, and cofactor treatment governs phenylalanine hydroxylase function and drug response. Hum Mol Genet 20:262826412011 


\section{Legend to Figures}

Figure 1: Calibration curves (linear regression) for Phe and Tyr using Phe-d5 and Tyr-d4 as internal standards for quantification. The ratio of analyte peak area and corresponding internal standard are plotted as a function of analyte concentration.

Figure 2: (a) Mass spectrum of wild-type PAH expressed in COS-1 cells, prepared with EZ:faast kit and measured by LC ESI-MSMS. Preparation by the kit includes 3 additional internal standards to correct for sample preparation variability. These are $d_{3}$-methionine, homophenylalanine and homoarginine (not shown in the spectrum below); (b) Linearity of Tyr production from $\mathrm{PAH}$ wild-type expressed in COS-1 cells transfected with increasing amounts of plasmid.

Figure 3: (a) PAH activities of various common $\mathrm{PAH}$ mutant proteins expressed in COS-1 cells and quantified by LC-ESI-MSMS. Activities are displayed as \% wt activity. All PAH activities are normalized with $\beta$-galactosidase activity for correction of transfection efficiency. (b) Western blot analysis of wild-type PAH and mutations tested for PAH activity. The same amount of total protein $(25 \mu \mathrm{g})$ was analyzed per lane. (c) PAH expression in all samples was normalized with $\beta$-actin expression and expressed as \% wild-type PAH expression. Nontransfected COS-1 cells do not show PAH protein.

Figure 4: (a) Comparison of absolute PAH activity in mouse tissues of wild-type (C57BL/6) and PKU (C57BI/6-Pahenu2) mice $(\mathrm{n}=3)$. Standard deviation results for PKU liver and brain are not displayed due to very small values. (b) Western blot analysis of PAH expression in liver (L), kidney (K) and brain (B) tissue from wild-type and PKU mice. As shown by $\beta$-actin loading control, increased protein amounts of brain tissue were loaded.

Figure 5: (a) PAH activity in various cell lines, eventually for use as cell host in in vitro studies or previously analyzed in PAH metabolism. (b) Western blot analysis of protein 
lysates from various cell lines transfected with wild-type PAH probed for PAH expression. $20 \mu \mathrm{g}$ of total protein analyzed (5 $\mu \mathrm{g}$ of COS-1 wild-type due to high expression), NT=nontransfected 
Table 1: Standards used for the calibration curve of L-Tyr and L-Phe.

\begin{tabular}{||c|c|c|c|c|c|c|c|c|c|c|c|c|c|c||}
\hline STANDARD & 1 & 2 & 3 & 4 & 5 & 6 & 7 & 8 & 9 & 10 & 11 & 12 & 13 & 14 \\
\hline [Tyr] $\mu \mathrm{mol} / \mathrm{L}$ & 0 & 4 & 8 & 12 & 16 & 20 & 40 & 60 & 80 & 100 & 150 & 200 & 250 & 350 \\
\hline [Phe] $\mu \mathrm{mol} / \mathrm{L}$ & 0 & 50 & 100 & 150 & 200 & 250 & 300 & 350 & 400 & 450 & 500 & 550 & 600 & 700 \\
\hline
\end{tabular}


Table 2: Imprecision data of Phe and Tyr quantification determined with wild-type, R261Q and R158Q PAH samples. The intra- and inter-assays were performed with individual cell lysates $(n=6)$. All PAH activities are normalized by co-transfection with pSV- $\beta$ gal.

\begin{tabular}{|c|c|c|c|c|c|c|}
\hline & \multicolumn{2}{|c|}{ Wt PAH } & \multicolumn{2}{|c|}{ p.R261Q } & \multicolumn{2}{|c|}{ p.R158Q } \\
\hline Intra-assay $(n=6)$ & $\begin{array}{c}\text { Mean (SD) } \\
\mu \mathrm{mol} / \mathrm{L}\end{array}$ & $\mathrm{CV}^{\prime}(\%)$ & $\begin{array}{c}\text { Mean (SD) } \\
\mu \mathrm{mol} / \mathrm{L}\end{array}$ & $\mathrm{CV}^{\prime}(\%)$ & $\begin{array}{c}\text { Mean (SD) } \\
\mu \mathrm{mol} / \mathrm{L}\end{array}$ & $\mathrm{CV}^{\prime}(\%)$ \\
\hline Phe & 417.3 (37.2) & 8.92 & $339.8(9.1)$ & 2.68 & 436.4 (28.9) & 6.63 \\
\hline $\begin{array}{c}\text { Tyr } \\
\text { Inter-assay }(n=6)\end{array}$ & $83.2(9.0)$ & 10.81 & $142.2(3.4)$ & 2.38 & $7.7(0.5)$ & 6.16 \\
\hline Phe & $321.5(18.5)$ & 5.75 & $414.9(48.5)$ & 11.68 & $520.1(45.0)$ & 8.66 \\
\hline Tyr & $210.4(25.5)$ & 12.13 & $125.6(17.9)$ & 14.29 & $14.9(0.9)$ & 5.28 \\
\hline$\frac{\text { PAH Activity }}{\text { (mU/mg protein) }}$ & & & & & & \\
\hline $\begin{array}{l}\text { Intra-assay }(n=6) \\
\text { Inter-assay }(n=6)\end{array}$ & $\begin{array}{l}61.4 \\
28.5\end{array}$ & & $\begin{array}{l}16.6 \\
20.8\end{array}$ & & $\begin{array}{l}2.34 \\
2.71\end{array}$ & \\
\hline
\end{tabular}

$\mathrm{CV}=$ coefficient of variation

${ }^{2}$ Varying reactions conditions: $30 \mathrm{~min}$ reaction time and $24.5 \mu \mathrm{g}$ total protein in inter-assay compared to 15 min reaction time and $9.0 \mu \mathrm{g}$ total protein in intra-assay experiment 

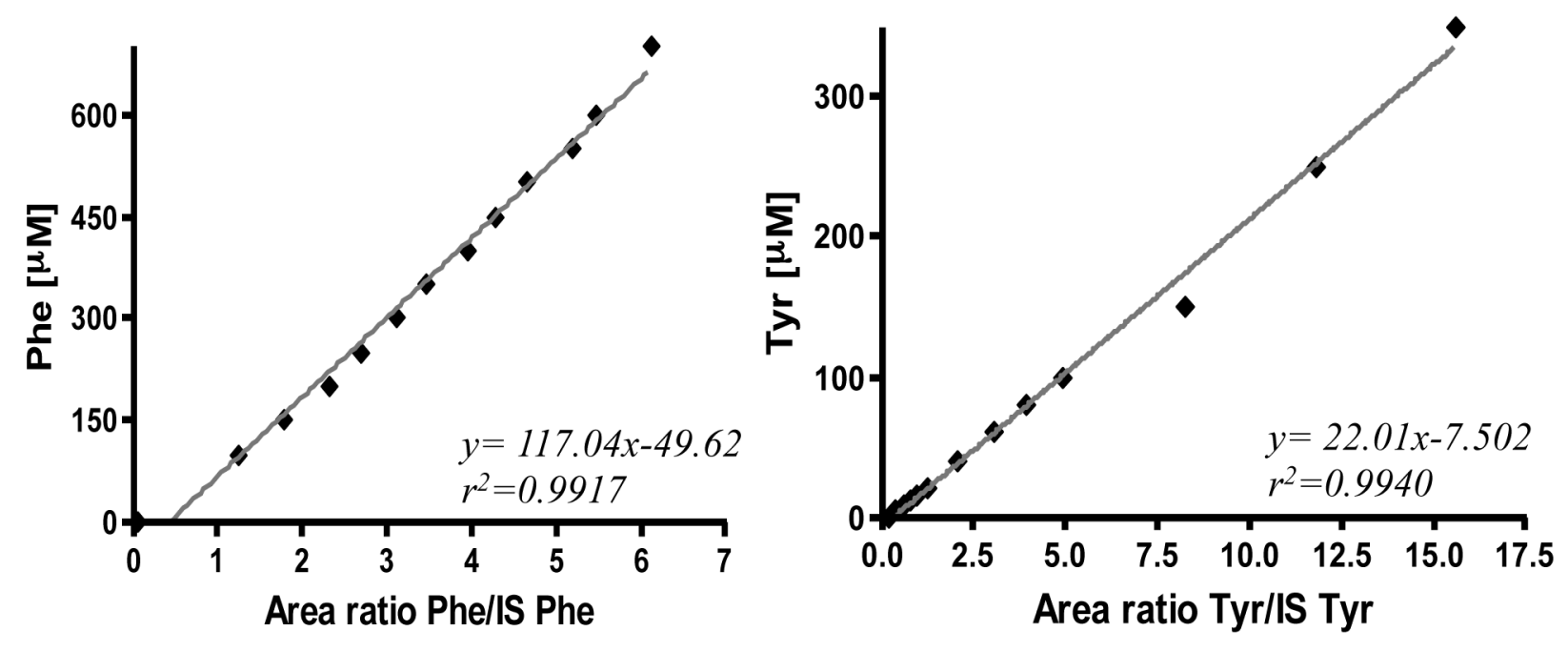
A

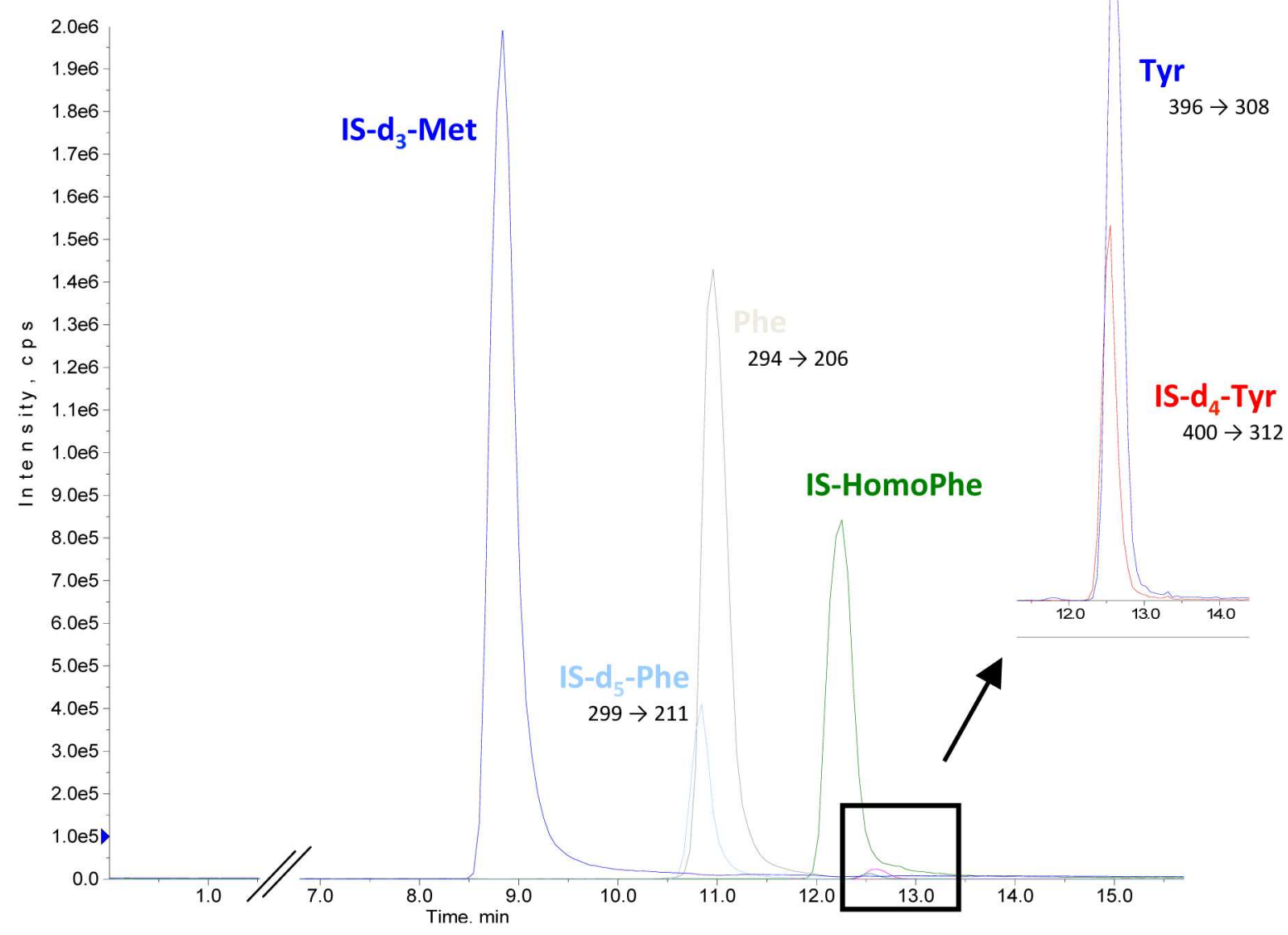

B

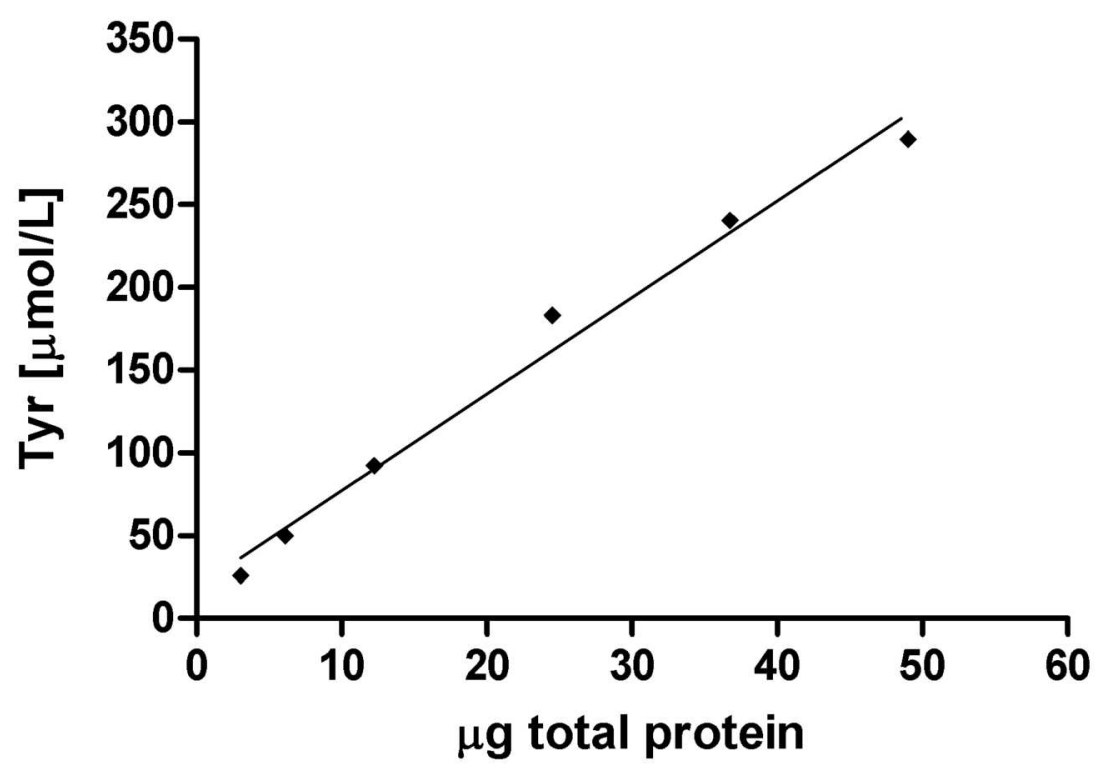




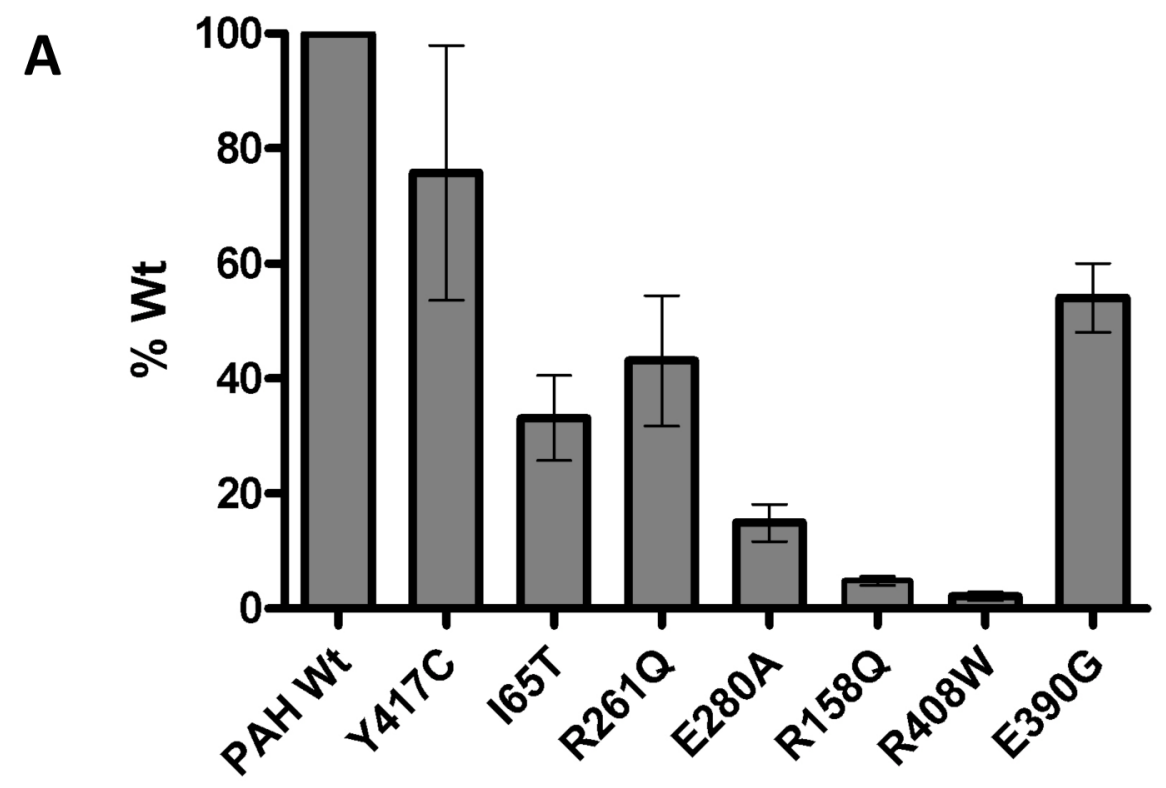

B

Wt Y417C 165T R261Q E280A R158Q R408W E390G COS-1

PAH

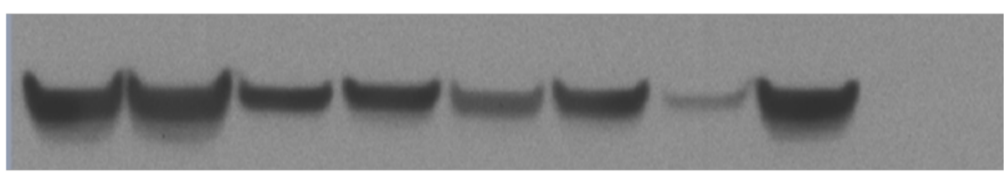

$\beta$-actin

C

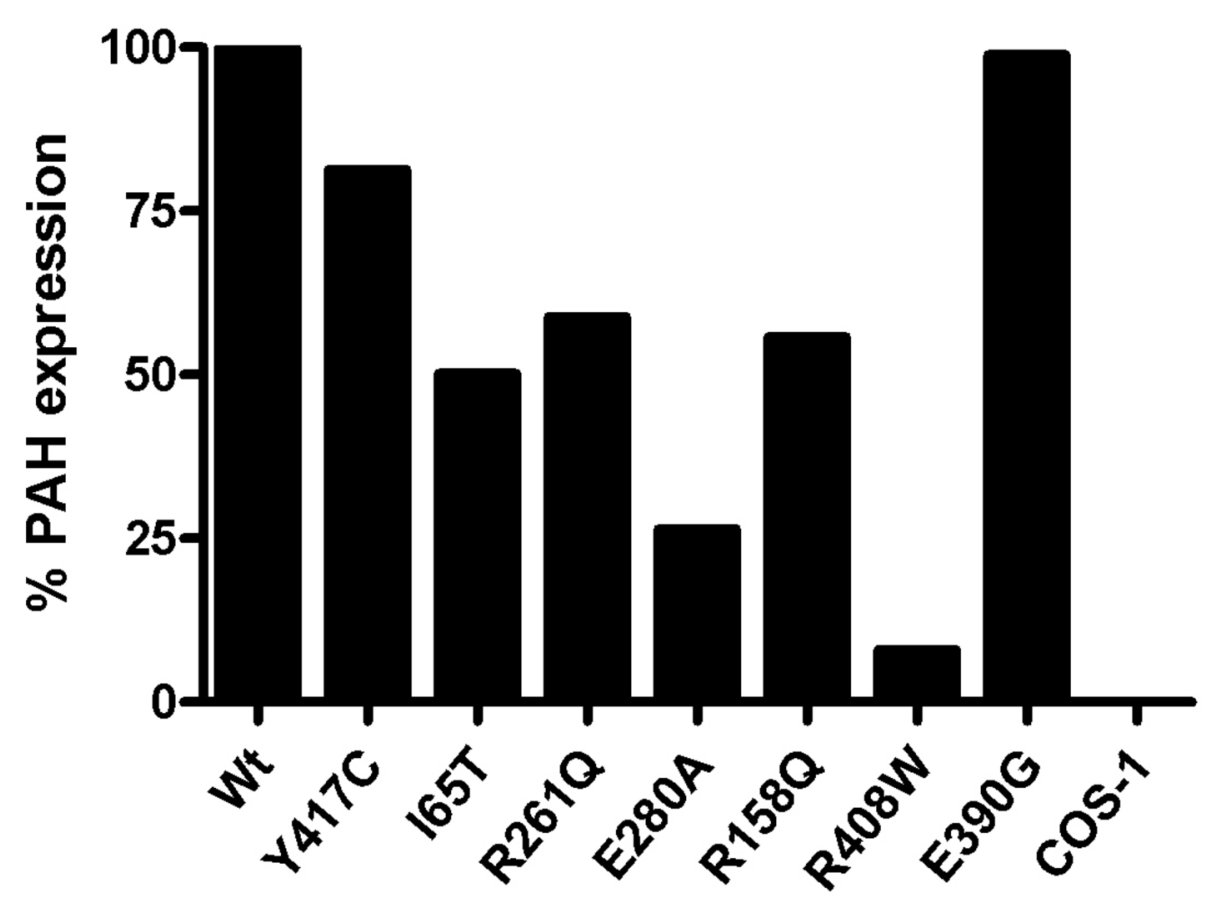




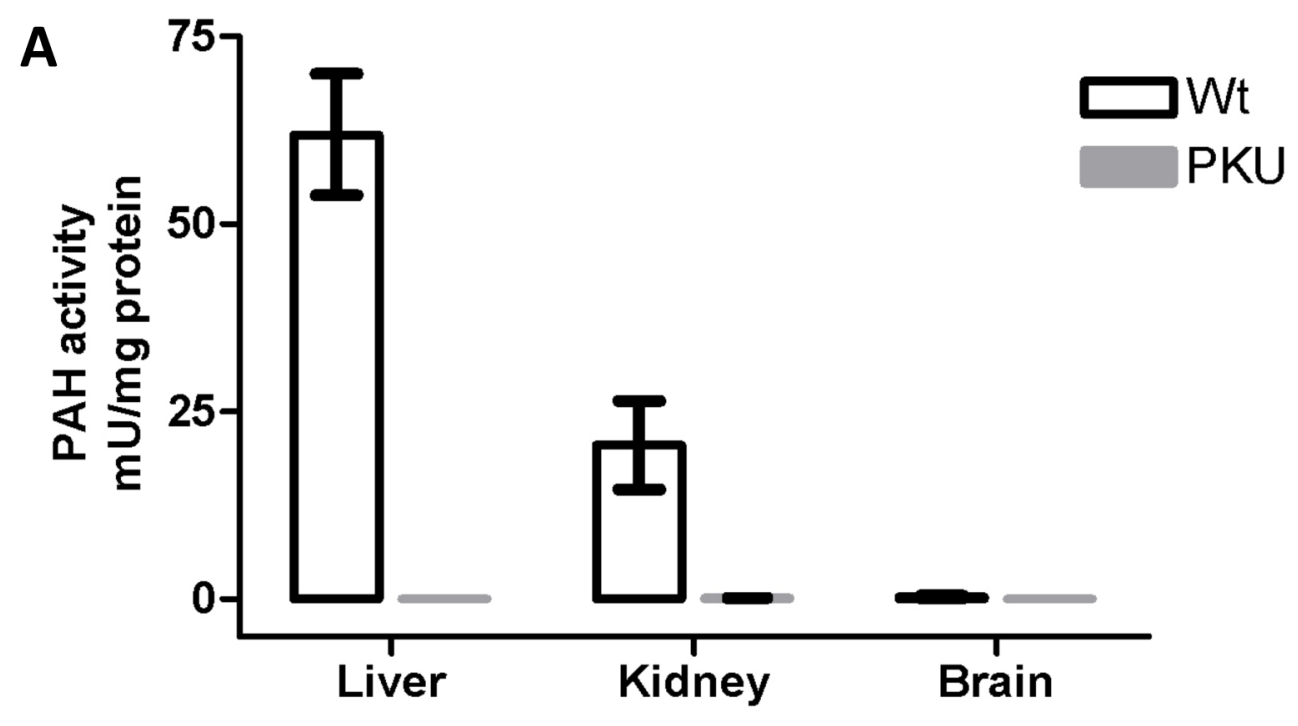

B

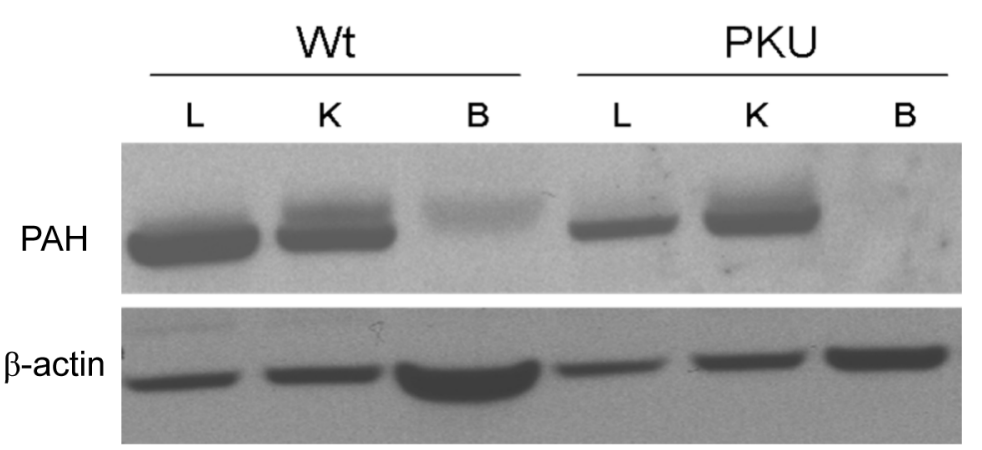

Figure

$\mathrm{PAH}$

$\beta$-actin 
A

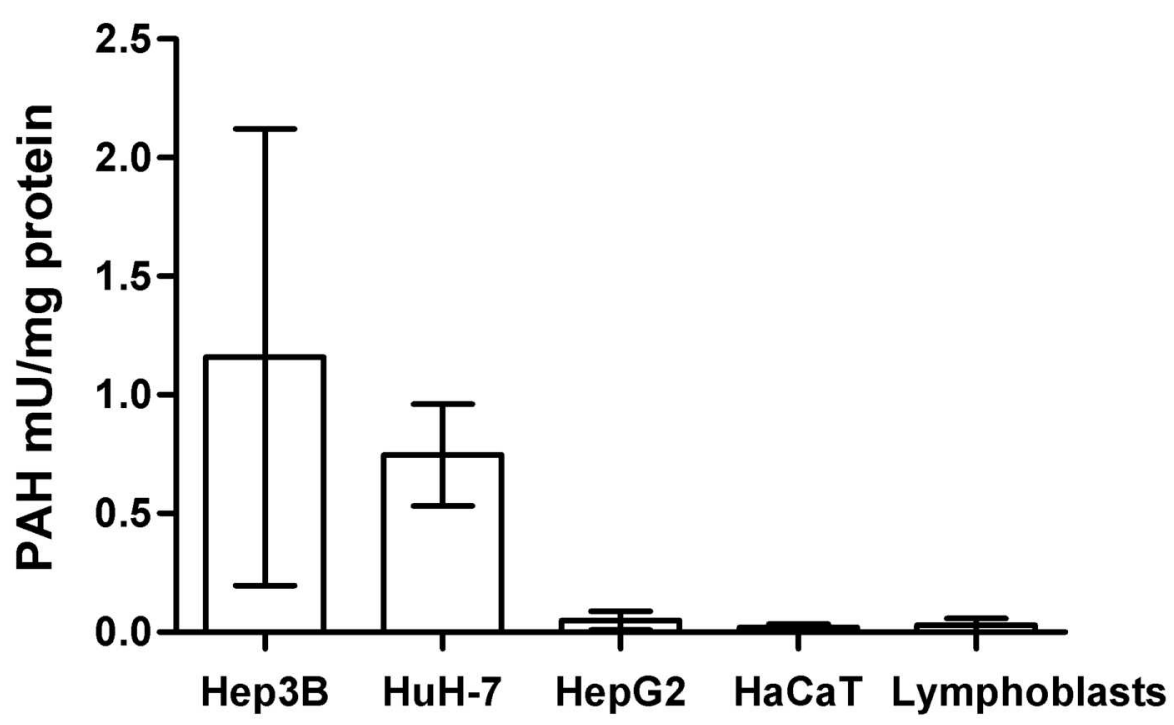

B

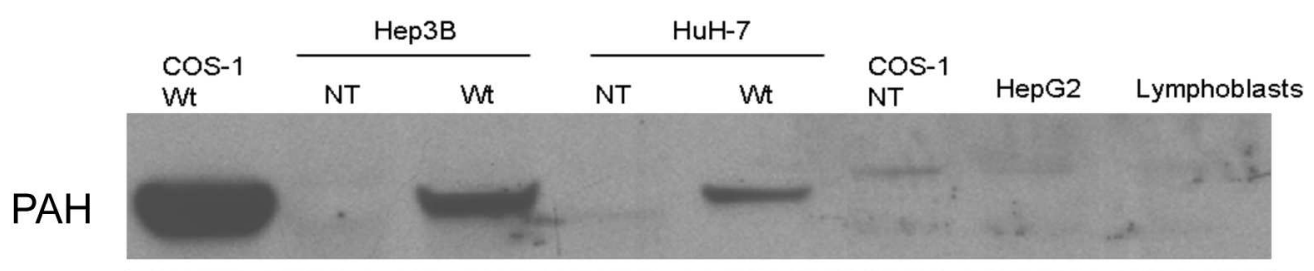

$\beta$-actin 